Place-Based Food Systems Viewpoint

\title{
Early lessons from The Food Commons: A new economic whole system approach for regional food
}

\section{PLACE-BASED FOOD SYSTEMS CONFERENCE: Making the Case, Making it Happen August 9-10th, 2018}

\author{
Jamie Harvie * \\ Institute for a Sustainable Future
}

Submitted December 14, 2018 / Published online August 22, 2019

Citation: Harvie, J. (2019). Early lessons from The Food Commons: A new economic whole system approach for regional food. Journal of Agriculture, Food Systems, and Community Development, 9(Suppl. 1), 77-86. https://doi.org/10.5304/jafscd.2019.091.045

Copyright (C) 2019 by the Author. Published by the Lyson Center for Civic Agriculture and Food Systems. Open access under CC-BY license.

\begin{abstract}
The Food Commons is an agro-ecological approach to local and regional food in which the health of employees, the community, and the commons are considered holistically. Food Commons Fresno is operationalizing the model with wholesale, food box, hub, commissary, and farming businesses managed through a linked forbenefit corporation and a community trust. Aside

* Jamie Harvie, P.E., is executive director of the Institute for a Sustainable Future and is nationally recognized for his extensive experience at the intersection of health, community, environment and healthcare. He is a founder of Commons Health and the Austin Health Commons and is a 2018 BALLE living economy fellow. Mr. Harvie is the author of numerous health and prevention journal articles and contributor to the textbook Integrative Medicine. He may be reached at harvie@isfusa.org or via http://www.jamieharvie.com.
\end{abstract}

from typical start-up challenges, the key hurdles include the cultural and economic unfamiliarity with ecological models and relational operating systems.

\section{Keywords}

Commons, Ecological Model, Agro-ecology, Holism, Food Systems, Integrative, Relational Model, Regenerative Capital, Inequality, Health, New Paradigm, Systems Thinking, Impact Investing

\section{Disclosure}

Mr. Harvie is the volunteer coordinating director of The Food Commons and serves on its board. He is also an independent consult, but for the presentation at the Place-Based Food Systems Conference and this resulting paper, his time and expenses were volunteered. 


\section{Introduction}

The economic model for the U.S. food and agricultural industry is predicated on scale, technology, centralization, and consolidation, serving large enterprises and global markets. It is widely recognized that this industrial food system-how we currently produce and distribute food-is intimately linked to the declining health of individuals, communities and the planet.

Over the last two decades, we have observed important and necessary responses to the industrialized food model. One notable example is The Food Commons (TFC), a new economic paradigm and whole system approach to local and regional food in which the health of employees, the community and the commons are considered holistically. Its prototype, Food Commons Fresno, is based in the heart of the industrial food industry, home to a nearly US $\$ 8$ billion agriculture industry, but also which hosts the zip codes with some of the highest rates of persistent poverty, pollution, obesity, diabetes, and food insecurity in the country.

\section{Our Failed Industrial Agriculture Paradigm}

It is widely recognized that our industrial food system is intimately linked to the deteriorating health of individuals, communities and the planet (Harvie, Mikkelsen, \& Shak, 2009). We are already experiencing significant impacts in the form of increased antibiotic-resistant bacteria, polluted air and water, food-borne pathogens, and the loss of mid-size family farms with negative impacts on the economies of rural communities and farm states. Obesity is now a global health concern, representing $21 \%$ of health costs in the United States (Harvard School of Public Health, n.d.). Poor nutrition is a risk factor for four of the six leading causes of death nationally: heart disease, stroke, diabetes, and cancer. According to recent data, 10\% percent of households with children (3.9 million households) were unable to provide adequate, nutritious food for their children (Coleman-Jensen, Nord, \& Singh, 2013). The global food system is responsible for up to $29 \%$ of climate change emissions (Vermeulen, Campbell, \& Ingram, 2012), leading to a host of climate-related health impacts such as heat stress and respiratory distress - conditions to which children and the elderly are the most vulnerable. Mirroring changes in manufacturing and retailing sectors, the industrial food model is now a highly consolidated economic model, characterized by global supply chains, commoditized foods, externalized health, and social and environmental costs. Farmers, as original stewards, have been largely supplanted by a plant and animal manufacturing system, supported by chemistry and technology. Experts have compared our industrial food system to a runaway train (Aubrun, Brown, \& Grady, 2006), and unless it is brought under control, the industrialized food system will continue to exert negative impacts on the health of people and planet.

\section{The Call for a Systems Paradigm}

Over the last several decades, the Good Food Movement has offered a critical response to the industrialized food model. The Good Food Movement is a broad collection of food system actorsconsumers, farmers, distributors, retailers, healthcare, and others-who have evolved a "bottom up" response through a call to action for good food for all. Good food is a holistic definition of food that bridges various food value systemsenvironment, access, justice, and nutrition-rather that a continued siloing of consumer, producer, and community needs and interests. The Good Food Movement has helped elevate the importance of food sovereignty, the right of people to healthy and culturally appropriate food and to define their own food systems.

At the global level, a variety of governmental reports underscore the need for a transformation of global food systems. Noteworthy is the International Assessment of Agriculture Knowledge, Science, and Technology for Development (IAASTD), funded by the United Nations organizations (McIntyre, Herren, Wakhungu, \& Watson, 2009). This report highlights the findings of global scientists charged with answering the question: What must we do differently to overcome persistent poverty and hunger, achieve equitable and sustainable development and sustain productive and resilient farming in the face of environmental crises (Ishii-Eiteman, 2009)? Their conclusion explicitly recognized that the health of the environment, 
social health of communities and the sustainability of agriculture are interrelated and must be considered holistically.

Recommendations include the need to promote value chains, fair trade, organic agriculture and local food systems that distribute benefits fairly and equitably along the chain, and the support of democratic institutions. Moreover, the report highlighted that the continued reliance on simplistic technological fixes will not reduce persistent hunger and poverty and could exacerbate environmental problems and worsen social inequity. This landmark report has become the basis for the UN Human Rights Commission support for agroecology, a local food systems model, and the Right to Food, providing a global framework that is consistent with the development of the Good Food Movement.

In 2015, an Institute of Medicine and National Research Council report concluded that the food system can be conceptualized as a complex, adaptive system and that "systemic approaches that take full account of social, economic, ecological, and evolutionary factors and processes will be required to meet challenges to the U.S. food system in the 21 st century" (Institutes of Medicine, 2015, p. 15). Similarly, through a study of five case studies, researchers recently concluded that, "adaptive governance of agro-ecosystems will likely hinge upon three paradigm shifts: viewing farmers and ranchers not only as food producers but also as land and water managers; seeking not yield maximization but rather resilient management of food ecosystems; and critically, as it transcends the production-system literature, engaging broad audiences not only as consumers but also citizens" (Chapman, et al., 2017). It is clear that food system design for a livable economy necessitates a broad cultural paradigm shift towards a new operating system in which the relationships between people, their communities and planet are paramount.

\section{The Food Commons Model}

Inspired by the grassroots movement and global call to action, TFC was developed to design and build a new food system model. TFC implicitly recognizes that that the failures of and the problems associated with the industrial food system are largely a function of its concentrated ownership, mechanistic design, and an industrial model based on efficiency and extraction. Moreover, a food system that truly meets the long-term needs of people and the planet should follow ecological principles, to reflect the complexity of its living systems. With this vision, TFC initiated convenings with a broad set of community actors to explore questions central to their vision:

- What would it take to bring to scale a nationwide regionalized food system?

- What is the necessary physical and organizational infrastructure?

- How do we capitalize and finance for the long term?

- How do we develop such a system to be integrative and holistic?

- What economic principles would ensure equity, fairness, and sustainability?

- How would such a system be governed?

- Why would this new system be desirable and how would it help people prosper and flourish?

In 2011, after a one-year community process,

\section{Figure 1. Food Commons Components}

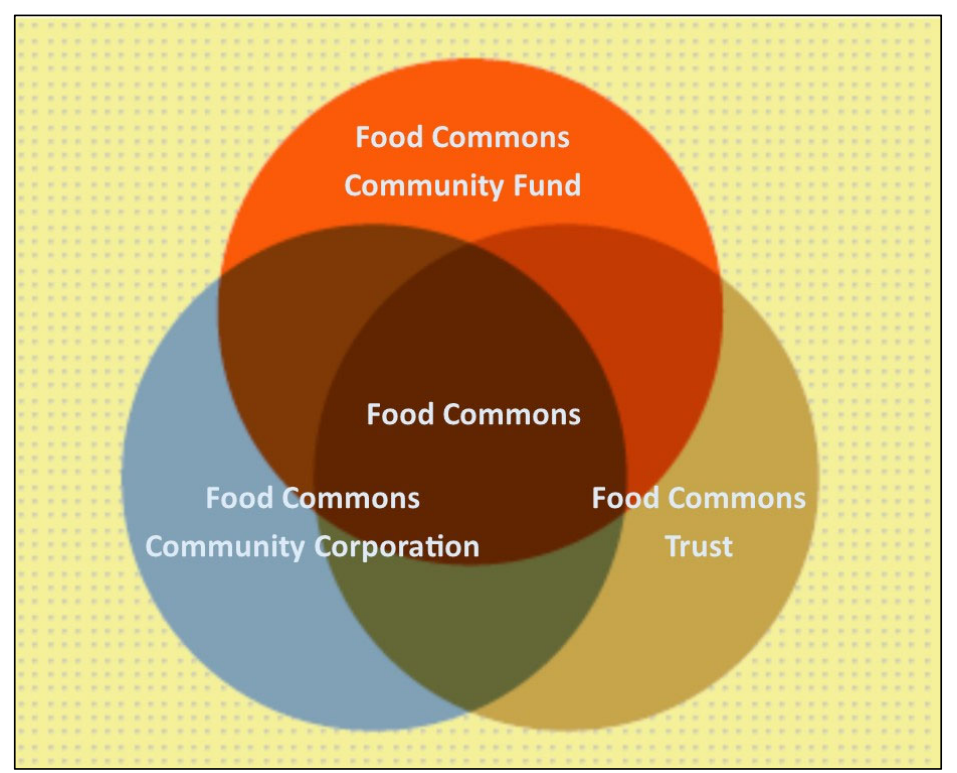


TFC published its findings in the document Food Commons 2.0 (The Food Commons, 2011). The vision outlines linked, localized food systems, each consisting of three interconnected organizational components (Figure 1) and governed by a set of core principles (Figure 2).
These components include:

1. A Food Commons Trust, a nonprofit, quasipublic entity to acquire and steward critical foodshed assets;

2. A Food Commons Community Fund, a

Figure 2. Principles for a Just and Sustainable Food Commons (The Food Commons, 2011)

\section{Fairness}

Across the entire value chain all participants' needs, from farmers and food business owners to agricultural and retail workers, are met in a balanced way, and all get a fair deal. Throughout the food system, the value of human labor is fairly recognized and appreciated. Individuals and institutions shall return to their communities' fair measure for what they receive.

\section{Sustainability and Stewardship}

In all aspects of food production and distribution, stewardship of our land and marine ecosystems is required to ensure that succeeding generations will have an equal or better opportunity to flourish from its resources. With respect to human relationships, active stewardship is also required to ensure a holistic vision of sustainability that includes ecological, social, and economic components. The true costs of food production should be reflected in market pricing to the fullest extent possible, though not all social, environmental or ethical values can be monetized.

\section{Economic Opportunity}

Create economic opportunities that facilitate the pursuit of Right Livelihood, so that people may earn a living without compromising the underlying principles of the Food Commons. Expand ownership opportunities for those who may not have access due to the high cost of infrastructure and expand career opportunities and access to good jobs with benefits and security, restoring hope to the unemployed and restoring craft and pride to labor.

\section{Food Sovereignty}

All people have the right to have access to quality, healthy food that is produced and distributed through environmentally and socially sustainable methods.

\section{Integration}

Create an integrated value chain, from farm to table, in order to achieve economic efficiency and fairness. Think systemically.

\section{Transparency}

Openly and honestly, share costs and pricing information essential to the equitable functioning of the value chain. Facilitate traceability of products, procedures and other relevant information throughout the value chain.

\section{Ethics and Accountability}

Governing bodies maintain the highest standards of credibility and ethical conduct, fair and accurate dissemination of information and full disclosure and accountability for their affairs. Representatives are accountable to the environment, to workers, to the public, and to future generations. Representatives set policies, but do not have any personal ownership in participating businesses.

\section{The Commons}

The segment of the food system that falls within the Food Commons is based on the establishment of shared and collectively managed infrastructure and resources, operating for the benefit of communities.

\section{Subsidiarity}

Decisions should be made at the most local level possible. Regional and national decisions should involve only those matters that are relevant to that level of governance, coordination and representation. The Food Commons will provide structures for overall coordination to allow decentralized management structures to operate efficiently and develop network linkages for formal and informal connections at the local and regional levels.

10. Reciprocity

The whole is responsible to all of the parts as well as the parts being responsible to the whole.

\section{Representation and Decision-making}

Equitable participation of the Food Commons stakeholders shall be present at all levels and entities of governance throughout the Food Commons, from farmers, to workers, to consumers. Decisions and deliberations must fairly represent the diversity of affected views and interests and not be dominated by any single view or interest. 
community-owned financial institution that provides capital and financial services to foodshed enterprises; and

3. A Food Commons Community Corporation, a locally owned, cooperatively integrated business enterprise that builds and manages foodshed-based physical infrastructure and facilitates the complex logistics of aggregation and distribution at different scales among all the moving parts of the system, and provides scale economies, business services, technical assistance and training to new small food businesses.

In simple terms, TFC model is a new economic paradigm for local and regional food. It seeks the efficiencies of vertical integration with the goal of sharing the benefits across the value chain and within the community, rather than extracting and exporting wealth. Central to the model is the recognition that farmland must be protected from privatization and held as a long-term public

\section{Figure 3. The Food Commons' Vertical Integration}

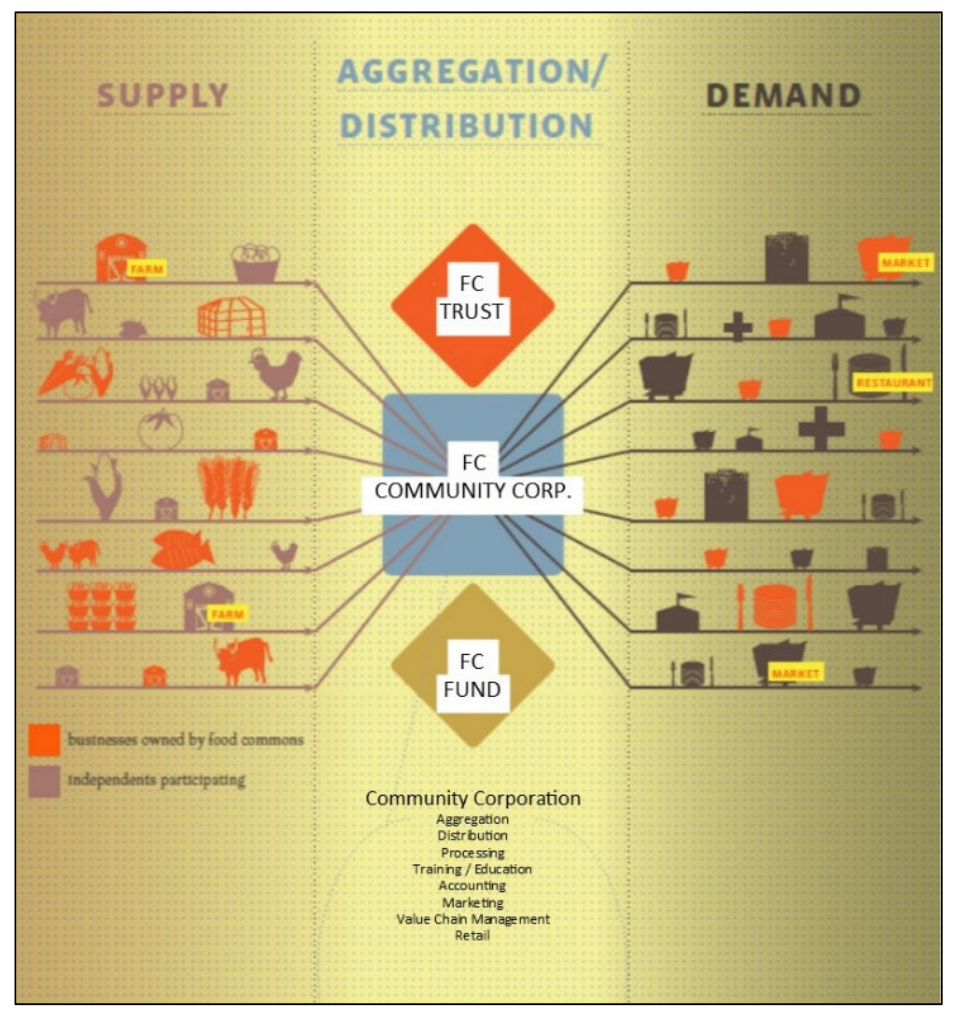

good. Through vertical (or holistic) integration and broad shared ownership, the Food Commons model aims to provide an economic alternative to the industrial food system for individuals, independent businesses, and producers seeking access to a community-owned food system operating in accordance with commonly shared principles of fairness, sustainability and accountability (Figure 3).

The Food Commons model follows Buckminster Fuller's maxim, "You never change things by fighting the existing reality. To change something, build a new model that makes the existing model obsolete." However, in order to build a prototype, TFC required a community willing and able to imagine and support an entirely new approach to food, health and community.

\section{Food Commons Fresno}

Fresno, California, was selected as the location of the first Food Commons prototype after it became clear there was a need, an invitation, and the support of community leadership. While Fresno County is home to a nearly US\$8 billion agriculture industry, it also hosts the zip codes with some of the highest rates of persistent poverty, pollution, and food insecurity in the country, and its poor residents are among the most isolated of any American city, regardless of race (Jargowsky, 2015). Yet these deficits mask many community assets. One example is the Fresno Business Council (FBC), whose board and membership span the public and private sectors and led the development of Fresno's Community Values. Written to serve as guiding principles for community action, they align closely with The Food Commons principles. The FBC also applies The Four Sphere Framework, a model developed to illustrate a systems approach to community business because "treating only symptoms means the problem is never really addressed or corrected. Instead, we must address the system holistically_from the fourth sphere" (Fresno Business Council, 2018, para. 1). Through a different sectoral lens, the FBC's holistic framework and associated 
guiding principles offered important community alignment with TFC model.

\section{Building the Prototype}

In 2015, TFC incorporated two of the three Food Commons components for its Fresno prototype: the Food Commons Fresno Trust and its fully owned business, Food Commons Fresno Community Corporation (henceforth, we will refer to both, interrelated entities as Food Commons Fresno [FCF]).

Operations began with the launch of Ooooby, FCF's organic produce box business, which has now delivered over 95,000 boxes to families across the region. In 2017, FCF took over operation of a 75-acre (30-hectare) certified organic farm, renamed Road 20 Farm, and is developing it into a showcase and training ground for regenerative practices, as well as a supplier of high-quality organic produce for local markets. FCF also established a hub facility in a disinvested neighborhood of Fresno to aggregate local produce from more than 60 small-scale organic and sustainable farms and ranches, and a separate facility to serve as a commissary kitchen for local food trucks and carts. FCF distributes product from its hub to area hospitals, institutions of higher learning, and wholesale restaurant customers. FCF's farm-to-fork operation now employs nearly 50 individuals, of whom an overwhelming majority reside in the low-income neighborhood it serves.

With the goal of community ownership and governance of the business, in 2018 FCF launched a direct public offering. Direct public offerings (DPOs) are a way for small businesses to raise capital directly from their communities and customers. Like in an initial public offering (IPO), people buy shares in a company, but unlike an IPO, the shares are not traded on the stock market or sold through investment banks. Also planned is an employee stock ownership program (ESOP), by far the most common form of employee ownership in the U.S. (National Center for Employee Ownership, 2018).

Planning was underway at the time of this writing for the development of a multifunctional Community Food Hub and grocery store in southwest Fresno in 2019. This area is a food desert, where the median income of the diverse population is less than US $\$ 25,700$ and the unemployment rate is 10.4 percent (PolicyLink \& Program for Environmental and Regional Equity, 2018). Other planned activities include expansion of the farm, Ooooby, and wholesale distribution businesses.

Through earned income, philanthropy, and significant internal and external support, FCF has been able to successfully scale operations; increase access to affordable, healthy food; create wellpaying urban and rural jobs; support vibrant community spaces and revitalize urban neighborhoods; practice regenerative agriculture; develop leadership and engagement in food system governance; and foster community pride and a sense of place. And FCF continues to wrestle with a host of challenges consistent with a start-up business: cash flow, tight budgets, development of an organizational culture, hiring, and more.

\section{What FCF Is Learning}

While FCF faces the daily challenges of any startup business, these trials are frequently compounded by the unique, holistic vision of The Food Commons model. Following are some of the trials and opportunities FCF and TFC are uncovering.

\section{Regenerative Capital Formation}

New paradigm models like TFC are trying to relocalize wealth and create regenerative capital. However, access to working capital is a constant battle in which TFC values and principals often feel held captive by markets that are seeking control or above-market returns. It has been difficult to distinguish between investors and impact investors, those willing to forgo market returns in exchange for true impact. Moreover, it has been surprising to FCF that they must pitch or "sell" the benefits of local capital formation, which FCF felt were selfevident. Ideally, forward-thinking impact investors would create a group that would work together, an impact investing network, which takes a systemic approach to their investments, similar to philanthropic affinity groups. As Rodney Foxworth, executive director of the Business Alliance for Local Living Economies (BALLE) aptly states, "if mainstream impact investing continues to operate 
within the culture of the 'free market' and prioritize capital returns, by definition it will promulgate economic injustice" (Foxworth, 2018, para. 7)). In short, the power and narrative of capital markets make it difficult to develop capital that is representative of the community versus extractive from the community.

\section{Let the Business be in Service to Principles and V alues} Embedded in the Legal DNA and Culture

TFC's board of directors represents more than a century of food-systems and systems-thinking experience and includes leading legal expertise. This experience helped inform the need to weave TFC's core principle and values into the legal structure of the organization before operationalizing work. For example, FCF was designed such that the FCF Trust would maintain local community control and oversight of the FCF Corporation so that it could never be bought or sold. With the FCF now operational within the broader extractive economy, this foresight feels invaluable in helping protect core values that might otherwise be tested and eroded.

\section{A New Operating System: The What is Easy, the How is Hard}

A shift from a linear model to an ecological model also shifts what is considered as important (Center for Ecoliteracy, 2018). This change in perception unleashes the emergence of new relationshipfocused operating styles characterized by networks and organizational approaches such as collaboration, teamwork, empowerment, and connection rather than hierarchies and control. The challenge is that the broader culture largely operates through the old paternalistic or mechanistic operating system, so many of the skills needed to work in a new paradigm business are difficult to find. From day one, the intent for FCF was to operate holocratically (Holocracy, n.d.), or holocratic-like, yet the challenging reality of a start-up with many moving parts resulted in the business defaulting to a traditional organizational structure. There was not enough time to learn, hire, and embed a new operating system and open a new business. FCF maintains formalized collaborative leadership as a goal as it shifts from start-up mode.
Find, Build, and Support Human Capital

For the TFC model to succeed, its leaders and advocates must represent the community; however, FCF is having trouble finding the necessary business experience within the local community. Many grassroots advocates drawn to TFC model bring an important holistic community approach but lack needed business skills. FCF is exploring how it might formalize training, coupled with the concept of the "opportunity of, by, and for the community." "This opportunity might also include the farming community and FCF's interest in assisting farmers in meeting their business, environmental, and community goals.

\section{To Unlock Our Potential We Need a New Model of Health}

What is health? At the heart of this question is a debate over the influence of the bio-medical model, which has shaped modern medicine and underpins our healthcare system and cultural beliefs about health. As it has the physical processes of disease as its focus, and assumes linear singular cause and effect, it is poorly equipped to accommodate multiple influences on health. The limits and associated costs to health and well-being of these linear models and embedded assumptions are now impossible to ignore. Although there is a more widespread appreciation for the significant role of social determinants or social and environmental factors, in health outcomes we too often overlook the fact that each of these factors works synergistically with one another and the individual. Similarly, overlooked yet equally important as these risk factors are qualitative factors such a sense of individual control and agency (Tamber \& Kelly, 2017).

FCF has discovered that many customers, funders, and community and healthcare leaders still consider foods' relationship to health as singularly related to nutrition. This limiting view diminishes the true benefit of good food and a holistic food system model to individual and community health. Health benefits include the sense of control and self-worth that comes from employment, the sense of community from shared ownership, the ecological health benefits from sustainable agriculture, and the sense of pride and connectedness from cultural 
food traditions — all of which holistically support whole health and wellbeing of the individual and community in the context of place.

The ecological model of health, or a systems worldview, is representative of new expansive science and by explaining the interconnections between individual, community, and planetary health, the ecological model provides an important unifying model. And, in our culture that is heavily influenced by a bio-medical model that represents $18 \%$ of the GDP, an ecological model is both difficult to explain and difficult to grasp, concealing the full benefits of holistic models such as TFC. Ironically, whole-paradigm models such as TFC offer an important means to catalyze health and wellbeing broadly.

\section{Wealth Creation and Root Cause Healing}

TFC views centralized ownership and organization of capital as critical root causes of the growing economic inequities, environmental degradations, food system dysfunctions, and health disparities. As the majority of these impacts fall disproportionally on the poor and on communities of color, the hierarchy of human value built into our economic system is glaring.

High inequality is linked to a sense of personal and public insecurity and increased consumption of resources and waste production, which negatively influence health through multiple means (Dorling, 2010; Warfield, 2016; Dorling, Barford, \& Wheeler, 2007; Philips, 2016). In a vicious loop, unequal access to education, poor health, and inadequate nutrition are reasons and results of inequality, thwarting the ability of individuals to thrive (Spratt, 2017). Those suffering from the highest economic disparity experience higher infant mortality and decreased mental health, life expectancy, levels of trust, altruism, social cooperation, reciprocity, and trust in political institutions (Attanasio, Fitzsimons, Grantham-McGregor, Meghir, \& Rubio-Condina, 2001; Bowles \& Gintis, 2011; Burns, Tomita, \& Kapadia, 2014; Elgar \& Aitken, 2011; Justino \& Moore, 2015; Organization for Economic Development and Cooperation, 2018).

According to a recent study, if current trends hold, median wealth for African Americans will fall to US $\$ 0$ by 2053 , while median wealth for Latino Americans will fall to US $\$ 0$ about two decades later. By 2020, white American households are projected to own 86 times more wealth than African American households, and 68 times more wealth than Latino households. (Collins, AsanteMuhammed, Nieves, \& Hoxie, 2017). This does not bode well for the health and welfare of the United States as a whole, where demographic projections indicate that whites will become the numerical minority in 2044 (Frey, 2014). Viewed holistically, wealth inequity may in fact represent one of the largest influences on the health of individuals, communities, and the planet (Harvie \& Guarneri, 2017). It is clear that we must acknowledge that until we change the status quo and capital is owned more widely and governed more locally, the negative health outcomes on society and the environment from capital deployment within the food system and elsewhere will be difficult to reverse, no matter the volume of nutritious food grown.

\section{Conclusion}

The Food Commons is but one entity working nationally to demonstrate a new systems approach. It offers an important new operational model that links the health of individuals, community, and the planet. TFC's strategy of systems change driven by community ownership and governance structures and beyond-the bottom-line returns links its work to a whole host of movements from climate change and environmental justice to worker equity and living wages, from cooperatives to community financing, as well as to the many facets of the sustainable agriculture, Good Food, and food democracy movements. TFC is helping elevate the collective benefit of a living systems model and the intractable resistance of culture and economy to change. The lessons from TFC suggest the need for rapid development of true regenerative capital, deepened networks, and collaborations with similar whole-system, place-based models and communities of practice across sectors. 


\section{References}

Attanasio, O., Fitzsimons, E., \& Grantham-McGregor, S., Meghir, C., \& Rubio-Codina, M. (2001). Early childhood development: Identifying successful interventions and the mechanisms behind them (Policy brief). London: International Growth Center. https://www.theigc.org/wp-content/uploads/2014/10/Attanasio-Et-Al-2012-Policy-Brief.pdf

Aubrun, A., Brown, A., \& Grady, J. (2006). Conceptualizing US food systems with simplifying models: Findings from Talk Back Testing. Frameworks Institute. Retrieved from http://www.frameworksinstitute.org/workshops/broccoli/foodSystems.pdf

Bowles, S., \& Gintis. (2011). A cooperative species: Human reciprocity and its evolution. Princeton, N.J.: Princeton University Press. https://doi.org/10.23943/princeton/9780691151250.001.0001

Burns, J. K., Tomita, A., \& Kapadia, A. S. (2014). Income inequality and schizophrenia incidence in countries with high levels of income inequality. International Journal of Social Psychiatry, 60(2), 185-196. https://doi.org/10.1177/0020764013481426

Center for Ecoliteracy. (2012). Systems thinking. Retrieved from https://www.ecoliteracy.org/article/systems-thinking

Chapman, M., Klassen, S., Kreitzman, M., Semmelink, A., Sharp, K., Singh, G., \& Chan, K. M. A. (2017). 5 key challenges and solutions for governing complex adaptive (food) systems. Sustainability, 9(9), 1594. https://doi.org/10.3390/su9091594

Coleman-Jensen, A., Nord, M., \& Singh, A. (2013). Household food security in the United States in 2012 (Economic Research Report No. ERR-155). Washington, D.C.: U.S. Department of Agriculture, Economic Research Service. https://www.ers.usda.gov/publications/pub-details/?pubid $=45132$

Collins, C., Asante-Muhammed, D., Nieves, E., \& Hoxie, J. (2017). The road to zero wealth. Prosperity Now and Institute for Policy Studies. Retrieved from https://www.mintpressnews.com/wp-content/uploads/2017/09/The-Road-to-Zero-Wealth FINAL.pdf

Dorling, D. (2010). Injustice: Why social inequality persists. Bristol, UK: Policy Press.

Dorling, D., Barford, A., \& Wheeler, B. (2007). Health impacts of an environmental disaster: A polemic. Environmental Research Letters, 2(4), 045007. https://doi.org/10.1088/1748-9326/2/4/045007

Elgar, F. J., \& Aitken, F. (2011). Income inequality, trust and homicide in 33 countries. European Journal of Public Health, 21(2), 241-246. https://doi.org/10.1093/eurpub/ckq068

Food Commons, The. (2011). The Food Commons 2.0. Retrieved from http://www.thefoodcommons.org/images/FoodCommons_2-0.pdf

Foxworth, R. (2018, February 18). Wealth inequality and the fallacies of impact investing [Blog post]. Retrieved from the Medium website: https://medium.com/balle/wealth-inequality-and-the-fallacies-of-impact-investing-eea902924309

Fresno Business Council. (2018). The Fourth Sphere-A systems approach. Retrieved from http://fresnobc.org/project/fourth-sphere/

Frey, W. H. (2014, December 12). New projections point to a majority minority nation in 2044 [Blog post]. Retrieved from the Brookings Institution's Avenue blog: https://www.brookings.edu/blog/the-avenue/2014/12/12/new-projectionspoint-to-a-majority-minority-nation-in-2044/

Harvard School of Public Health. (n.d.). Obesity prevention source: Economic costs. Retrieved November 30, 2018, from http://www.hsph.harvard.edu/obesity-prevention-source/obesity-consequences/economic/

Harvie, J., \& Guarneri, M. (2017). Healthy people, healthy planet. Unpublished manuscript.

Harvie, J., Mikkelsen, L., \& Shak, L. (2009). A health care prevention agenda: Sustainable food procurement and agriculture policy. Journal of Hunger and Environmental Nutrition, 4(3-4), 409-429. https://doi.org/10.1080/19320240903329055

Holocracy. (n.d.). Self-management practices for organizations. Retrieved November 2018 from https://www.holacracy.org/

Institute of Medicine \& National Research Council. (2015). A framework for assessing effects of the food system. Washington, D.C.: The National Academies Press.

Jargowsky, P. (2015). Architecture of segregation: Civil unrest, the concentration of poverty, and public policy. The Century Foundation. Retrieved from https://tcf.org/content/report/architecture-of-segregation 
Justino, P., \& Moore, M. (2015). Inequality: Trends, harms and new agendas (IDS Evidence Report 144). Brighton, UK: Institute of Development Studies. Retrieved from https://www.ids.ac.uk/publications/inequality-trends-harms-and-new-agendas/

McIntyre, B. D., Herren, H. R., Wakhungu, J., \& Watson, R. T. (2009). International assessment of agricultural knowledge, science, and technology: Global Report Washington, D.C.: Island Press.

National Center for Employee Ownership . (2018). How and employee stock ownership program works. Retrieved from https://www.nceo.org/articles/esop-employee-stock-ownership-plan

Organization for Economic Development and Cooperation. (2018). OECD data. Retrieved from https://data.oecd.org/

Philips, B. J. (2016). Inequality and the emergence of vigilante organizations: The case of Mexican autodefensas. Comparative Political Studies, 50(10), 1358-1389. https://doi.org/10.1177/0010414016666863

PolicyLink \& Program for Environmental and Regional Equity. (2018). Advancing health equity and inclusive growth in Fresno County. Retrieved from the National Equity Atlas website: https://nationalequityatlas.org/sites/default/files/FresnoProfile final.pdf

Spratt, S. (2017). Equality, security and sustainability: In search of virtuous circles (IDS Evidence Report 219). Brighton, UK: Institute of Development Studies. Retrieved from https://www.ids.ac.uk/publications/equality-security-and-sustainability-in-search-of-virtuous-circles/

Tamber, P. S., \& Kelly, B. (2017). Fostering agency to improve health: Twelve principles key to the future of health. Seattle: Bridging Health \& Community. Retrieved from https://www.pstamber.com/reports/executive-summary-fostering-agency-to-improve-health/

Vermeulen, S. J., Campbell, B., \& Ingram, J. S. (2012). Climate change and food systems. Annual Review of Environment and Resources, 37, 195-222. https://doi.org/10.1146/annurev-environ-020411-130608

Warfield, R. (2016) Inequality: A real risk to our planet. Resurgence \& Ecologist, 297, 20-22. https://www.resurgence.org/ 